Research Article

\title{
Performance of potato (Solanum tuberosum L.) varieties with and without straw-mulch at Shankharapur, Kathmandu, Nepal
}

\author{
Kalyani Shrestha ${ }^{1 *}$, Shrawan Kumar Sah ${ }^{1}$, Reeti Singh ${ }^{2}$ and Yam Narayan Devkota ${ }^{3}$ \\ ${ }^{1}$ Faculty of Agriculture, Agriculture and Forestry University, Rampur, Chitwan, Nepal \\ ${ }^{2}$ PMAMP, PIU, Bhaktapur, Nepal \\ ${ }^{3}$ Directorate of Agriculture Development, Province No.5, Nepal \\ *Correspondence: kalyanitab1@ gmail.com \\ *ORCID: https://orcid.org/0000-0001-5792-3461 \\ Received: July 25, 2020; Accepted: September 25, 2020; Published: October 30, 2020 \\ (c) Copyright: Shrestha et al. (2020). \\ (c) (1) (8) \\ This work is licensed under a Creative Commons Attribution-Non Commercial 4.0 \\ International License.
}

\begin{abstract}
The suitability of crop varieties in a particular location determines the productivity of crops. A field experiment was conducted from February to May 2020 at Shankharapur, Kathmandu, Nepal to evaluate the growth and productivity of potato varieties with and without mulch. Five potato varieties (Cardinal, Janakdev, Khumal Bikas, MS- 42.3, Panauti Local) were evaluated under straw-mulch and no-mulch conditions. The treatments were arranged in two factorial Randomized Complete Block Design (RCBD) with 3 replications. The results revealed that the highest tuber yield was produced by Janakdev (34.29 $\left.\mathrm{t} \mathrm{ha}^{-1}\right)$ followed by Panauti Local $(29.52 \mathrm{t}$ $\left.\mathrm{ha}^{-1}\right)$. Similarly, straw-mulch gave higher yield $\left(25.9 \mathrm{t} \mathrm{ha}^{-1}\right)$ as compared with no mulch condition $\left(21.73 \mathrm{t} \mathrm{ha}^{-1}\right)$. The higher tuber yield in the Janakdev and Panauti Local was because of higher tuber weight per hill, higher number and weight of medium size (50 -100 g) and oversize (> $100 \mathrm{~g})$ tuber per hill. Similarly, higher yield in straw mulch was due to higher number and weight of tuber per hill. Higher gross return, net return was observed and the benefit cost ratio was greater in varieties Janakdev (4.08) and Panauti Local (3.53) and rice straw mulch (2.88). Therefore, potato varieties Janakdev and Panauti Local with straw mulch are most suitable for Kathmandu like climate for improving productivity and profitability.
\end{abstract}

Keywords: Mulch, Potato, Variety, Yield

Correct citation: Shrestha, K., Sah, S.K., Singh, R., \& Devkota, Y.N. (2020). Performance of potato (Solanum tuberosum L.) varieties with and without straw-mulch at Shankharapur, Kathmandu, Nepal Journal of Agriculture and Natural Resources, 3(2), 193-204. DOI: https://doi.org/10.3126/janr.v3i2.32506

\section{INTRODUCTION}

Common potato (Solanum tuberosum L.) is the most important food crop in the world surpassed by rice, wheat and maize and is consumed worldwide as an important non- cereal staple crop. In the context of Nepal, the average per capita potato consumption of potatoes is $29.9 \mathrm{~kg} /$ year (CBS, 2019). The area under potato cultivation is 193,997 ha with an average production and productivity of 3,112,947 tons and $16.04 \mathrm{t} \mathrm{ha}^{-1}$ respectively (MOALD, 2020). The crop solely accounts for $6.57 \%$ of Agricultural Gross Domestic Product (AGDP) and 2.17\% Gross Domestic Product (GDP). The major potato growing districts in Nepal are Dolakha, Kavre, Bara, Illam, Jhapa (CBS, 2019). It is used as subsidiary food as part of 
Journal of Agriculture and Natural Resources (2020) 3(2): 193-204

ISSN: 2661-6270 (Print), ISSN: 2661-6289 (Online)

DOI: https://doi.org/10.3126/janr.v3i2.32506

vegetables in Terai region, whereas as staple food in Hill and Mountain Regions of Nepal (Subedi et al., 2019). It is commercial non-cereal produce of Nepal and an important source of income for the farmers (Upadhyay et al., 2020a).

Nepal lies among the top countries where potato contributes deliberately for general human diet. The demands for potatoes are increasing with qualities with variations in consumption forms. Yield in the country is about. 1.5 times low compared to developed countries (Upadhyay et al., 2020b). According to the farmers, lack of seed tubers of suitable varieties in desired bulks during the growing season hinders the farmers from getting benefits of new varieties in the zone. Ghimire (2015) mentioned about the dissatisfaction of the farmers with the available potato varieties and dearth of climate resistant, early maturing varieties. The share of area planted under modern varieties is relatively lower in Nepal compared to many Southeast and South Asian countries (Gatto et al., 2018).

National Potato Research Program (NPRP) is responsible for varietal development, research and promotion of potatoes in the nation (Gairhe et al., 2017). The income of farmers and nation's nutritional security are highly influenced through the adoption of improved potato varieties. (Ghimire, 2005). The varietal variations in characters provide diversity in natural resistances to pests, diseases, and climatic conditions. Cultivars include landraces and varieties which are developed by breeders.

Mulching is a crucial agronomic practice which modifies the physical environment of the soil by suppressing weeds, conserving soil moisture and improving soil fertility (Yoo-Jeong et al., 2003). Weeds are responsible for high potential loss, which are reported to reduce significantly on mulching. Mulching has roles in addressing irrigation issues, mulches could be organic as well as inorganic. The organic materials include straw, husk, cover crop etc, while inorganic mulches include black or silver plastic (Bharati et al., 2020). Ibeawuchi et.al. (2015) mentioned the application of organic mulches for yield increment, weed control, erosions and sustaining soil productivity by improving physical and biological soil conditions. Application of mulch was found to improve emergence, tubers per plant and yield. (Singh \& Ahmed, 2008; Dhakalet al., 2011).

Proper trials, training and seed source affects the for improved varieties (Upadhyay et al., 2020c) and suitable management practices. Therefore, the present experiment was carried on with the objective to determine growth and productivity of potato varieties with and without straw-mulch application.

\section{MATERIALS AND METHODS}

\section{Experimental site}

A farmers land at Shankharapur -7, Kathmandu designated as the potato zone under Prime Minister Agriculture Modernization Project (PMAMP) was chosen for the study, which lies

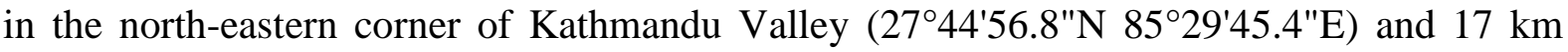
way from the city of Kathmandu.The soil in the experimental site was silty with an average $\mathrm{pH}$ of 6.5-6.7. The meteorological data for cropping season was extracted from the database at NASA power. The average maximum and minimum mean daily temperature were $14.5^{\circ} \mathrm{C}$ and $26.03^{\circ} \mathrm{C}$ respectively and the maximum precipitation was $82.09 \mathrm{~mm}$ (Figure 1). 


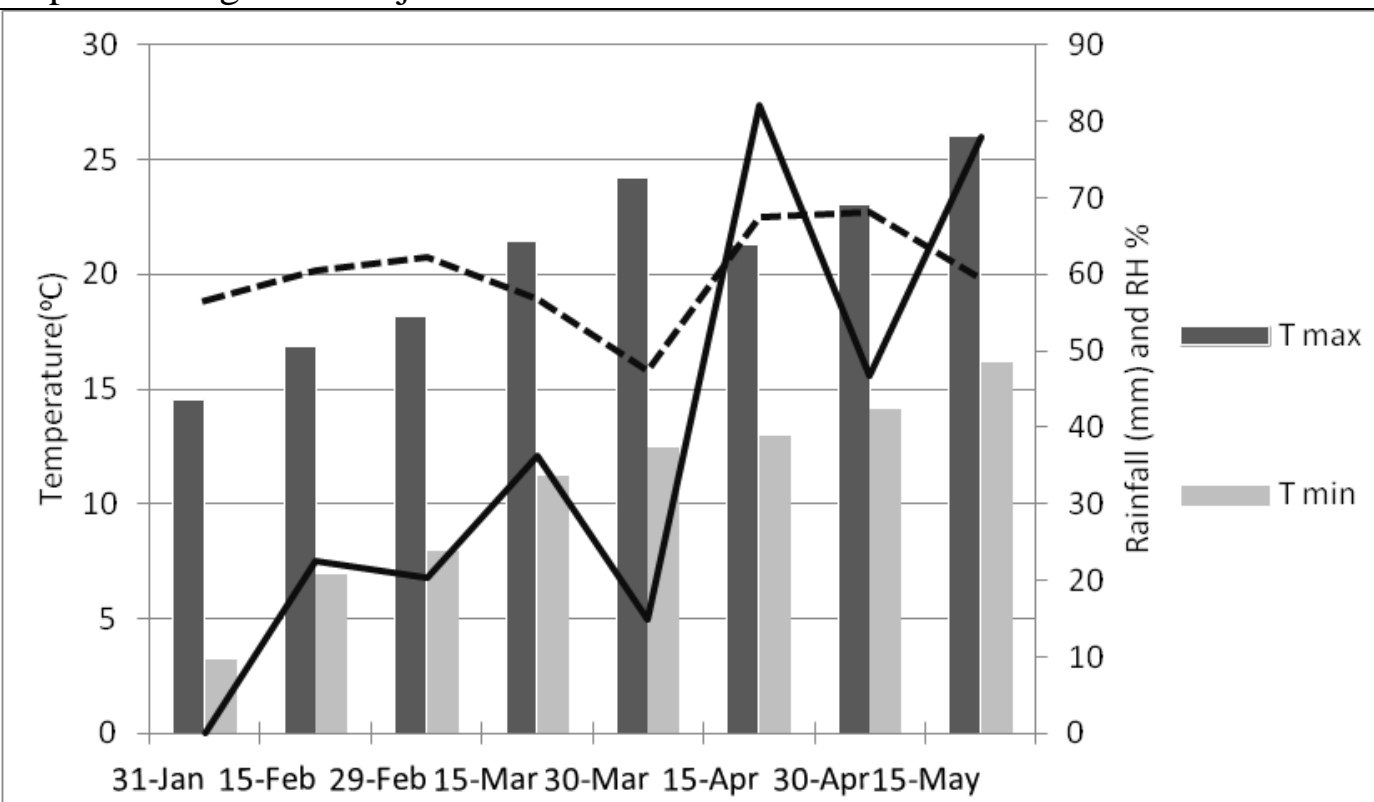

Figure 1. Weather data of experimental location at 15 days interval during the growing season of potato in 2020 at Sankhu, Kathmandu, Nepal (NASA power, n.d.)

\section{Plant materials}

The treatments consisted of a combination of five potato varieties, including 2 registered varieties viz. Cardinal, MS- 42.3, 2 released varieties viz. Janakdev, Khumal Bikas, and a local cultivar viz. Panauti Local. All the tubers were brought from a certified source at Kushadevi, Panauti, Kavrepalanchowk.

Table 1: Potato varieties used as treatments in the experiments

\begin{tabular}{llllll}
\hline S.N. & Variety & Source & Maturity Days & Status & Yield (t/ha) \\
\hline 1 & Cardinal & Holland & $90-110$ & Registered & $20-25$ \\
2 & Janakdev & CIP & $110-130$ & Released & $25-30$ \\
3 & Khumal Bikas & Nepal & $90-110$ & Released & $25-30$ \\
4 & MS-42.3 & Nepal & $90-110$ & Registered & $25-30$ \\
5 & Panauti Local & Nepal & $90-110$ & Local & $15-20$ \\
\hline
\end{tabular}

(Upadhayay et al., 2020b; AITC, 2020)

\section{Experimental design and treatment details:}

The experiment was laid out in Randomized Complete Block Design (RCBD) with ten treatments, each replicated thrice. The treatments consisted of combination of five potato varieties (Cardinal, Janakdev, Khumal Bikas, MS- 42.3, Panauti Local) and two levels of mulch (rice straw mulch and no mulch).

\section{Cultural practices}

Five well sprouted tubers of about fifty grams with 2-3 eyes were sown $30 \mathrm{~cm}$ apart on each ridge. Fertilizers at the rate of 100:100:60 kg N: $\mathrm{P}_{2} \mathrm{O}_{5}: \mathrm{K}_{2} \mathrm{O}$ and FYM 10 ton per hectare was applied. All the FYM, $\mathrm{P}_{2} \mathrm{O}_{5}, \mathrm{~K}_{2} \mathrm{O}$ and $50 \% \mathrm{~N}$ were applied at the time of final land preparation and remaining $50 \% \mathrm{~N}$ was applied one month after potato planting. Rice straw mulch was applied one week after planting. 
Journal of Agriculture and Natural Resources (2020) 3(2): 193-204

ISSN: 2661-6270 (Print), ISSN: 2661-6289 (Online)

DOI: https://doi.org/10.3126/janr.v3i2.32506

\section{Data observation}

The observations on phenology, growth, yield attributes and yield were taken from 5 randomly selected plants from each plot. The data on cost of cultivation, gross return, net return and benefit cost ratio were calculated on current input and output price.

\section{Statistical analysis}

All the recorded data was entered into MS Excel and further subjected to analysis of variance (ANOVA). R-Studio was used for analyzing data. Duncan's multiple range test (DMRT) was conducted for mean separations by selecting 5\% level of significance. (Gomez \& Gomez, 1984; Shrestha, 2019).

\section{RESULTS AND DISCUSSION}

\section{Effect of variety and mulch on Growth characters}

The results of days to germination, plant height, average number of leaves, branches and average stem girth are presented in Table 1. All the parameters were significantly influenced by varieties but not by mulching. Varieties Janakdev and Khumal Bikas germinated earlier than Cardinal, MS 42.3 and Panauti Local. Germination of varieties is genetically controlled and varieties vary in dormancy period (Struik, 2007). Differences in days to sprouting attributed to variety was also reported by Mohammadi et al. (2014).

The plant heights of Janakdev and Panauti Local were statistically similar but significantly taller than all other varieties at 45 DAS. At 60 DAS, the highest height was observed in Janakdev and the least in Khumal Bikas, whereas all the other varieties showed intermediate plant height. Few morphological characteristics including plant height are highly dependent on varieties due to its genetic variations (Pradhan et al., 2011). Environmental influence and additive genetics control the expression of these traits as mentioned by Khan et al. (2000).

The average number of leaves was statistically lower at 45 DAS in Khumal Bikas compared to the other varieties. At 60 DAS, MS-42.3 and Janakdev had the highest leaf number and whereas it was least in Khumal Bikas and Panauti Local. The variation is due to the association of varieties with leaf number and leaf development in a complex manner (Kirby et al., 1985).

Maximum number of branches were observed in Cardinal and MS-42.3 in the 45 DAS and least in Khumal Bikas. The number of aerial branches can be attributed to the number of eyes and sprouts present per eye (Hawkes, 1990). Similarly, Mondal et.al. (2001) and Sattar et al. (1970) reported similar differences in branch number among varieties. Janakdev followed by Panauti Local had the highest girth at 45 DAS, which was least for MS-42.3. The variations in girth are due to the genetic characteristics. 
Table 2. Days to germination, plant height, average number of leaves, branches and average stem girth as influenced by varieties and mulch conditions of potato in 2020 at Sankharapur, Kathmandu, Nepal

\begin{tabular}{|c|c|c|c|c|c|c|c|}
\hline \multirow[t]{2}{*}{ Treatments } & \multirow{2}{*}{$\begin{array}{l}\text { Days to } \\
\text { germination }\end{array}$} & \multicolumn{2}{|c|}{ Plant height $(\mathrm{cm})$} & \multicolumn{2}{|c|}{$\begin{array}{c}\text { Average number of } \\
\text { leaves }\end{array}$} & \multirow{2}{*}{ 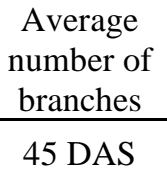 } & \multirow{2}{*}{$\begin{array}{l}\text { Stem girth } \\
(\mathrm{cm})\end{array}$} \\
\hline & & 45 DAS & 60 DAS & $45 \mathrm{DAS}$ & $60 \mathrm{DAS}$ & & \\
\hline \multicolumn{8}{|l|}{ Varieties } \\
\hline Cardinal & $32.67^{\mathrm{a}}$ & $17.43^{\mathrm{b}}$ & $48.10^{\mathrm{b}}$ & $35.90^{\mathrm{a}}$ & $60.36^{\mathrm{b}}$ & $5.80^{\mathrm{a}}$ & $2.88^{\mathrm{bc}}$ \\
\hline Janakdev & $25.00^{\mathrm{b}}$ & $24.01^{\mathrm{a}}$ & $56.70^{\mathrm{a}}$ & $33.60^{\mathrm{a}}$ & $63.55^{\mathrm{ab}}$ & $3.13^{\mathrm{b}}$ & $3.65^{\mathrm{a}}$ \\
\hline KhumalBikas & $22.00^{\mathrm{b}}$ & $14.31^{\mathrm{b}}$ & $32.10^{c}$ & $14.33^{\mathrm{b}}$ & $26.61^{c}$ & $1.46^{\mathrm{c}}$ & $2.88^{\mathrm{bc}}$ \\
\hline MS- 42.3 & $32.00^{\mathrm{a}}$ & $15.10^{\mathrm{b}}$ & $45.83^{\mathrm{b}}$ & $36.23^{\mathrm{a}}$ & $72.75^{\mathrm{a}}$ & $5.53^{\mathrm{a}}$ & $2.75^{\mathrm{c}}$ \\
\hline PanautiLocal & $33.67^{\mathrm{a}}$ & $21.74^{\mathrm{a}}$ & $46.46^{\mathrm{b}}$ & $28.23^{\mathrm{a}}$ & $45.23^{c}$ & $3.10^{\mathrm{b}}$ & $3.38^{\mathrm{ab}}$ \\
\hline $\operatorname{SEm}( \pm)$ & 1.09 & 1.17 & 1.59 & 2.82 & 3.92 & 0.31 & 0.18 \\
\hline LSD & 3.26 & 3.49 & 4.73 & 8.39 & 11.66 & 0.93 & 0.54 \\
\hline F test & $* *$ & $* *$ & $* *$ & $* *$ & $* *$ & $* *$ & $* *$ \\
\hline \multicolumn{8}{|c|}{ Mulch condition } \\
\hline Straw-mulch & 28.93 & $18.15^{\mathrm{a}}$ & $45.00^{\mathrm{a}}$ & 28.90 & 53.53 & 3.86 & 3.13 \\
\hline No-mulch & 29.20 & $18.88^{\mathrm{a}}$ & $46.68^{\mathrm{a}}$ & 30.41 & 53.87 & 3.74 & 3.09 \\
\hline $\operatorname{SEm}( \pm)$ & 0.69 & 0.21 & 1.00 & 1.78 & 2.48 & 0.19 & 0.11 \\
\hline $\operatorname{LSD}(0.05)$ & 1.97 & 2.10 & 2.99 & 5.54 & 7.37 & 0.59 & 0.34 \\
\hline $\mathrm{CV}(\%)$ & 9.25 & 15.55 & 8.51 & 24.85 & 17.90 & 20.23 & 14.46 \\
\hline Grand mean & 29.06 & 18.52 & 45.84 & 29.66 & 53.70 & 3.80 & 3.11 \\
\hline
\end{tabular}

Treatments means followed by common letter(s) within column are not significantly different among each other based on DMRT at $5 \%$ level of significance

\section{Effect of variety and mulch on Yield parameters}

The number of tubers per hill was significantly influenced by varieties and mulch (Table2). Significantly higher number of tubers per hill was observed in MS 42.3. Cardinal and Panauti Local had statistically similar number of tubers per hill but significantly lower than MS 42.3 and higher compared to Janakdev and Khumal Bikas. The significantly lowest number of tubers per hill was obtained from Khumal Bikas. Similarly, straw mulch produced higher number of tubers per hill than no mulch. Hawkes (1990) and Struik (2007) previously explained that the number of stems per tuber depends on the number of eyes which determines the tuber per hill. Luitel et al. in 2013 and 2014 and Gainju (2018) also reported significantly different tuber number per plant among varieties.

Tuber weight per hill was significantly influenced by varieties as well as mulch (Table 2). Variety Janakdev and Panauti Local had significantly higher weight of tubers per hill as compared to Khumal Bikas, MS-42.3and Cardinal, which were statistically similar to each other. Straw-mulch was found to significantly increase the weight of tubers per hill compared to no-mulch. Higher tuber weight per hill could be due to the response of varieties to the inputs and climate. Higher tuber weight in Janakdev among the tested varieties was 
Journal of Agriculture and Natural Resources (2020) 3(2): 193-204

ISSN: 2661-6270 (Print), ISSN: 2661-6289 (Online)

DOI: https://doi.org/10.3126/janr.v3i2.32506

previously attributed to its higher responsiveness to the fertilizers applied as reported by Adhikari in 2013.The weight of tuber per plot also was significantly different among the cultivars as observed by Poudel and Karkee (2016) in Terathum, Nepal.

Table 2 shows that the weight per tuber was influenced by varieties but not mulch condition. The weight per tuber was statistically higher in Khumal Bikas followed by Janakdev. The weight per tuber in MS-42.3 and Cardinal was statistically similar and lower compared to Panauti Local, Janakdev and Khumal Bikas. The weight per tuber depends on the tuber size distribution among varieties and the tuber number per hill.

Table 3: Tuber weight and number per hill, weight per tuber and number of nonmarketable tuber as influenced by varieties and mulch conditions of potato in 2020 at Sankhu, Kathmandu, Nepal

\begin{tabular}{lccc}
\hline Treatments & Tuber weight per hill $(\mathrm{kg})$ & Number of tubers per hill & Weight per tuber $(\mathrm{g})$ \\
\hline Varieties & & & \\
Cardinal & $0.32^{\mathrm{b}}$ & $11.73^{\mathrm{b}}$ & $28.41^{\mathrm{d}}$ \\
Janakdev & $0.61^{\mathrm{a}}$ & $9.76^{\mathrm{c}}$ & $63.46^{\mathrm{b}}$ \\
Khumal Bikas & $0.37^{\mathrm{b}}$ & $4.53^{\mathrm{d}}$ & $82.37^{\mathrm{a}}$ \\
MS- 42.3 & $0.33^{\mathrm{b}}$ & $15.73^{\mathrm{a}}$ & $21.13^{\mathrm{d}}$ \\
Panauti Local & $0.56^{\mathrm{a}}$ & $12.16^{\mathrm{b}}$ & $48.51^{\mathrm{c}}$ \\
\hline SEm( \pm$)$ & 0.03 & 0.65 & 3.70 \\
LSD $(0.05)$ & 0.09 & 1.94 & 11.00 \\
\hline F-test & $* *$ & $* *$ & $* *$ \\
\hline Mulch condition & & & 47.96 \\
Straw-mulch & $0.47^{\mathrm{a}}$ & $12.30^{\mathrm{a}}$ & 49.60 \\
No-mulch & $0.40^{\mathrm{b}}$ & $9.18^{\mathrm{b}}$ & 2.34 \\
\hline SEm $( \pm)$ & 0.02 & 0.41 & 6.95 \\
LSD $(0.05)$ & 0.062 & 1.22 & $\mathrm{~ns}$ \\
F-test & $*$ & $* *$ & 18.59 \\
CV $(\%)$ & 18.55 & 14.90 & 48.78 \\
Grand mean & 0.43 & 10.74 &
\end{tabular}

Treatments means followed by common letter( $s$ ) within column are not significantly different among each other based on DMRT at $5 \%$ level of significance

Effect of variety and mulch on tuber distribution and yield

The tuber distribution by weight and number per hill of varieties after grading, under mulch and no-mulch is shown in Table 3. The distribution of number and weight of tuber was significantly influenced by varieties but not by mulch condition. Significantly higher number and weight of small size tubers $(<50 \mathrm{~g})$ was reported in MS-42.3. Khumal Bikas had statistically least number and weight of tubers weighing below $50 \mathrm{~g}$. Panauti Local at par with Janakdev had significantly higher number and weight of mid-size tubers (50-100 g) per hill. The small size and mid-size tubers were least in number and weight in Khumal Bikas. Similarly, number of over-size tubers $(>100 \mathrm{~g})$ was highest in Janakdev and Panauti Local 
Journal of Agriculture and Natural Resources (2020) 3(2): 193-204

ISSN: 2661-6270 (Print), ISSN: 2661-6289 (Online)

DOI: https://doi.org/10.3126/janr.v3i2.32506

followed by Khumal Bikas. However, oversize tubers per hill weighed highest in Janakdev and Khumal Bikas. Significantly lowest number and weight of oversize tubers was found in MS-42.3 and Cardinal. The distribution of number and weight of tuber per hill depends on the varietal characteristics and determines its utility as per purpose. The tubers weighing below $50 \mathrm{~g}$ are the seed size tubers. Mid-size tubers are desirable for consumption whereas, tubers weighing beyond $100 \mathrm{~g}$ are less desirable for consumption yet are marketable. Tested cultivars varied significantly for number of tubers after grading as observed in Okhaldhunga, Nepal (Ghimire et al., 2020). . Higher Coefficient of Variance was observed due to the wide range of tuber sizes borne for the different varieties used, the number and weight of tubers as per grades showed extreme high and low values showing greater variation from the parameter mean.

Both varieties and mulch were found to have significant influence in the yield of potato tubers (Table 3). Highest yield was observed in Janakdev (34.29 $\mathrm{t} \mathrm{ha}^{-1}$ ) followed by Panauti Local $\left(29.52 \mathrm{t} \mathrm{ha}^{-1}\right)$ which were statistically similar to each other. Khumal Bikas $\left(20.60 \mathrm{t} \mathrm{ha}^{-1}\right)$ was statistically similar but higher compared to MS-42.3 (18.11t ha-1) and Cardinal (16.57 t $\left.\mathrm{ha}^{-1}\right)$. Janakdev and Panauti Local had higher tuber weight per hill, higher number and weight of medium size (50 -100 g) and oversize (> $100 \mathrm{~g}$ ) tuber per hill resulting in comparatively higher yields. The varieties have different attainable yields based on their inherent characteristics. Genetic variability is considered an important factor for obtaining high yield (Sattar et al., 1970). Difference in yield can be attributed to difference in growth character where the genetic make-up is responsible along with variation in nutrient usage among varieties and the climate (Zelelew et al., 2016). Similarly, Hijmans (2003) mentioned that the environmental suitability of cultivars influences the yield. Similar influence of mulch and variety on growth and yield parameters were observed (Dhakal et al., 2011)

The observations of higher yield in Janakdev is similar to the observations by Magar (2016). Higher yield in the local cultivar, Panauti Local is similar to the observations by Khatri and Shrestha in 2004, where the yield in some local cultivars under trials were superior or equal to the check varieties. Significance in yield and resistance among clones were reported in Bhaktapur by Gainju (2018). Similar performance as a promising cultivar was reported for Panauti Local and was recommended for the mid-hills of Nepal by Upadhyay et al. in 2020.

Straw-mulch treatment gave significantly higher yield of $25.9 \mathrm{t} \mathrm{ha}^{-1}$ compared to no-mulch condition $\left(21.73 \mathrm{t} \mathrm{ha}^{-1}\right)$. The higher yield in straw mulch was due to higher number and weight of tuber per hill. Higher tuber yields of potato for straw mulching over no mulch is attributed to suitable temperature and humidity conditions in the soil (Bharati et al., 2020). Ibeawuchi et al. (2015), Yoo-Jeong et al. (2003) and Ahmed (2017) had reported similar results of greater yields were reports for potatoes under mulch conditions. Enhanced growth and yield could also be attributed to reduced root competition due to weed suppression and stimulated microbial activity. 
Table 4: Tuber distribution by weight and number and yield as influenced by varieties and mulch conditions of potato in 2020 at Sankhu, Kathmandu, Nepal

\begin{tabular}{|c|c|c|c|c|c|c|c|}
\hline Treatments & $\begin{array}{l}\text { Number } \\
\text { of small } \\
\text { size } \\
\text { tubers } \\
(<50 \mathrm{~g}) \\
\end{array}$ & $\begin{array}{l}\text { Weight } \\
\text { of small } \\
\text { size } \\
\text { tubers } \\
(<50 \mathrm{~g}) \\
\end{array}$ & $\begin{array}{l}\text { Number of } \\
\text { mid-size } \\
\text { tubers }(50- \\
100 \mathrm{~g})\end{array}$ & $\begin{array}{l}\text { Weight of } \\
\text { mid-size } \\
\text { tubers } \\
(50-100 \\
\text { g) }\end{array}$ & $\begin{array}{l}\text { Number of } \\
\text { oversize } \\
\text { tubers } \\
(>100 \mathrm{~g})\end{array}$ & $\begin{array}{c}\text { Weight } \\
\text { of } \\
\text { oversize } \\
\text { tubers } \\
(>100 \mathrm{~g}) \\
\end{array}$ & $\begin{array}{c}\text { Tuber yield } \\
\left(\mathrm{t} \mathrm{ha}^{-1}\right)\end{array}$ \\
\hline \multicolumn{8}{|l|}{ Variety } \\
\hline Cardinal & $4.50^{\mathrm{b}}$ & $96.74^{\mathrm{ab}}$ & $1.48^{\mathrm{ab}}$ & $67.39^{\mathrm{bc}}$ & $0.07^{\mathrm{c}}$ & $7.12^{\mathrm{c}}$ & $16.57^{\mathbf{b}}$ \\
\hline Janakdev & $2.80^{\mathrm{c}}$ & $67.68^{b c}$ & $1.51^{\mathrm{a}}$ & $87.40^{\mathrm{ab}}$ & $1.29^{\mathrm{a}}$ & $150.09^{\mathrm{a}}$ & $34.29^{\mathrm{a}}$ \\
\hline Khumal Bikas & $0.87^{\mathrm{d}}$ & $23.51^{\mathrm{d}}$ & $0.68^{c}$ & $48.33^{c}$ & $0.92^{\mathrm{ab}}$ & $128.05^{\mathrm{ab}}$ & $20.60^{\mathrm{b}}$ \\
\hline MS- 42.3 & $5.73^{\mathrm{a}}$ & $107.65^{\mathrm{a}}$ & $1.12^{\mathrm{b}}$ & $43.96^{\mathrm{c}}$ & $0.33^{\mathrm{bc}}$ & $16.11^{\mathrm{c}}$ & $18.11^{\mathrm{b}}$ \\
\hline Panauti Local & $2.80^{\mathrm{bc}}$ & $57.04^{\mathrm{cd}}$ & $1.65^{\mathrm{a}}$ & $103.61^{\mathrm{a}}$ & $1.05^{\mathrm{a}}$ & $106.01^{b}$ & $29.52^{\mathrm{a}}$ \\
\hline $\operatorname{SEm}( \pm)$ & 0.38 & 11.88 & 0.12 & 10.34 & 0.20 & 12.71 & 1.82 \\
\hline $\operatorname{LSD}(0.05)$ & 1.14 & 35.30 & 0.35 & 30.72 & 0.59 & 37.7 & 5.41 \\
\hline F-test & $* *$ & $* *$ & $* *$ & $* *$ & $* *$ & $* *$ & $* *$ \\
\hline \multicolumn{8}{|l|}{$\begin{array}{l}\text { Mulch } \\
\text { condition }\end{array}$} \\
\hline Straw-mulch & 3.57 & 75.78 & 1.35 & 73.81 & 0.87 & 89.55 & $25.90^{\mathrm{a}}$ \\
\hline No-mulch & 2.97 & 65.28 & 1.21 & 66.46 & 0.59 & 73.40 & $21.73^{\mathrm{b}}$ \\
\hline $\operatorname{SEm}( \pm)$ & 0.24 & 7.51 & 0.07 & 6.54 & 0.12 & 8.04 & 0.43 \\
\hline $\operatorname{LSD}(0.05)$ & 0.72 & 22.33 & 0.35 & 19.43 & 0.37 & 23.89 & $3.24 *$ \\
\hline F-test & $\mathrm{ns}$ & $\mathrm{ns}$ & $\mathrm{ns}$ & ns & ns & ns & $*$ \\
\hline $\mathrm{CV} \%$ & 28.89 & 41.27 & 23.02 & 36.11 & 66.86 & 38.22 & 18.74 \\
\hline Grand mean & 3.24 & 70.52 & 1.28 & 70.14 & 0.73 & 81.48 & 23.82 \\
\hline
\end{tabular}

Treatments means followed by common letter(s) within column are not significantly different among each other based on DMRT at $5 \%$ level of significance

\section{Effect of variety on morphological characteristics of tubers}

Table 4 shows the shape of tuber, eye depth, tuber color, tuber flesh color for the varieties used. The five varieties differed for shape of tuber, eye depth, tuber color and tuber flesh color. The tuber color was red in two varieties, with one variety of blue, white and yellow each. Eye depth was deep and shallow for two varieties each and shallow in one of the varieties. Similar characterizations were listed for the varieties by Upadhyay et al. in 2020.

Table 5: Morphological characteristics of tubers as influenced by varieties and mulch conditions in potato in 2020 at Sankhu, Kathmandu, Nepal

\begin{tabular}{llllll}
\hline S.N. & Variety & Shape of tuber & Eye depth & Tuber color & $\begin{array}{l}\text { Tuber flesh } \\
\text { color }\end{array}$ \\
\hline 1 & Cardinal & Oval & Medium & White & Pale yellow \\
2 & Janakdev & Oblong & Shallow & Red & Pale yellow \\
3 & Khumal Bikas & Oval & Medium & Red & Pale yellow \\
4 & MS-42.3 & Oblong & Deep & Blue & Pale yellow \\
5 & Panauti Local & Round & Deep & Red & Yellow \\
\hline
\end{tabular}




\section{Effect of variety and mulch on Economic analysis}

The data for cost of cultivation, gross return, net return and B:C ratio is presented in Table 7. The gross return, net return and $\mathrm{B}: \mathrm{C}$ ratio observed was highest for Janakdev and Panauti Local and least in Cardinal. Cost of was significantly higher under straw-mulch compared to no mulch due to the added cost of rice-straw. However, the B:C ratio in straw-mulch field compared to no-mulch was found to be higher by $10.32 \%$.

Table 6: Economic analysis as influenced by varieties and mulch conditions potato in 2020atSankhu, Kathmandu, Nepal

\begin{tabular}{|c|c|c|c|c|}
\hline Treatments & $\begin{array}{l}\text { Total cost of cultivation } \\
\left(\text { NRs. } 000 \mathrm{ha}^{-1}\right)\end{array}$ & $\begin{array}{c}\text { Gross return } \\
\left(\text { NRs. } 000 \mathrm{ha}^{-1}\right)\end{array}$ & $\begin{array}{c}\text { Net return } \\
\left(\text { NRs. } 000 \text { ha }^{-1}\right) \\
\end{array}$ & $\begin{array}{c}\mathrm{B}: \mathrm{C} \\
\text { ratio }\end{array}$ \\
\hline \multicolumn{5}{|l|}{ Varieties } \\
\hline Cardinal & 351240.3 & $530364^{\mathrm{c}}$ & $179124.1^{\mathrm{c}}$ & $1.50^{\mathrm{c}}$ \\
\hline Janakdev & 351240.3 & $1440369.3^{\mathrm{a}}$ & $1089128.9^{a}$ & $4.08^{\mathrm{a}}$ \\
\hline KhumalBikas & 351240.3 & $865354.1^{\mathrm{b}}$ & $514113.8^{b}$ & $2.45^{\mathrm{b}}$ \\
\hline MS- 42.3 & 351240.3 & $760719.1^{b}$ & $409478.8^{\mathrm{b}}$ & $2.16^{\mathrm{b}}$ \\
\hline Panauti Local & 351240.3 & $1239893.7^{\mathrm{a}}$ & $888653.4^{\mathrm{a}}$ & $3.53^{\mathrm{a}}$ \\
\hline $\operatorname{SEm}( \pm)$ & & 207.58 & 207.58 & 0.21 \\
\hline $\operatorname{LSD}(0.05)$ & & 226191.7 & 226191.7 & 0.63 \\
\hline F-test & & $* *$ & $* *$ & $* *$ \\
\hline \multicolumn{5}{|c|}{ Mulch condition } \\
\hline Straw-mulch & $364540.3^{\mathrm{a}}$ & $1051292.1^{\mathrm{a}}$ & 686751.7 & 2.88 \\
\hline No-mulch & $337940.3^{b}$ & $883388.2^{\mathrm{b}}$ & 545447.8 & 2.61 \\
\hline $\operatorname{SEm}( \pm)$ & & 131.28 & 131.28 & 0.13 \\
\hline $\operatorname{LSD}(0.05)$ & & $143056.2^{* * *}$ & 143056.2 & 0.40 \\
\hline F-test & & $* *$ & $\mathrm{~ns}$ & ns \\
\hline CV\% & & 19.27738 & 30.26748 & 18.98 \\
\hline Grand mean & 351240.3 & 967340.1 & 616099.8 & 2.74 \\
\hline
\end{tabular}

Treatments means followed by common letter(s) within column are not significantly different among each other based on DMRT at $5 \%$ level of significance

\section{CONCLUSION}

The yield, gross return, net return and B:C ratio were higher for varieties Janakdev and Panauti Local and for straw mulch treatment. Hence, Janakdev and Panauti Local were the most suitable varieties of potato for Kathmandu like climate and straw mulch was better for increasing yield and income from potato.

\section{ACKNOWLEDGEMENTS}

The authors are very thankful to Agriculture and Forestry University, Rampur, Prime Minister Agriculture Modernization Project (PMAMP) and the farmers of Sankhu for providing the opportunity and support during the research. 
Journal of Agriculture and Natural Resources (2020) 3(2): 193-204

ISSN: 2661-6270 (Print), ISSN: 2661-6289 (Online)

DOI: https://doi.org/10.3126/janr.v3i2.32506

\section{Authors' Contributions}

K. Shrestha and S.K. Sah together planned and designed the experiment. K. Shrestha performed the experiment and analysis while S.K. Sah supervised throughout the experiment, result interpretation and manuscript development. R. Singh and Y. Devkota contributed in facilitating and supervising the experiment.

\section{Conflict of Interest}

The authors declare no conflicts of interest regarding publication of this manuscript.

\section{REFERENCES}

Adhikari, A. R. (2013). Effects of Micronutrients on Yield of Desiree and JanakDev potato at Kakre of Kavre District, Nepal. Karma Enterprises Pvt Ltd. Retrieved from http://12215510215.com/napnutriscience/Nepal-Potato-Charge-MM-cab-MM-spaMulti-micro-one.pdf

Ahmed, N. U., Mahmud, N. U., Hossain, A., Zaman, A. U., \& Chandra, S. (2017). Performance of mulching on the yield and quality of potato. International Journal of Natural and Social Sciences, 4(2), 07-13.

Bharati, S., Joshi, B., Dhakal, R., Paneru, S., Dhakal, S. C., \& Joshi, K. R. (2020). Effect of different mulching on yield and yield attributes of potato in Dadeldhura district, Nepal. Malaysian Journal of Sustainable Agriculture, 4(2), 54-58.

DOI: http://doi.org/10.26480/mjsa.02.2020.54.58

Bohl, W. H., \& Johnson, S. B. (2010). Commercial potato production in North America. Potato Association of America Handbook, 57, 38-48.

CBS. (2019). Retrieved from Centra Bureau of Statistics: https://cbs.gov.np/

Cirujeda, A., Aibar, J., Anzalone, Á., Martín-Closas, L., Meco, R., Moreno, M. M., Pardo, A., Pelacho, A. M., Rojo, F., Royo-Esnal, A., Suso, M. L., \& Zaragoza, C. (2012). Biodegradable mulch instead of polyethylene for weed control of processing tomato production. Agronomy for Sustainable Development. 32, 889-897.

Dhakal, R., Shakya, S. S., \& Basnet, K. (2011). Tuber yield and quality of potato chips as affected by mulch, variety, and potash levels under western Terai, Nepal. Agronomy Journal of Nepal, 2, 121-132. DOI: https://doi.org/10.3126/ajn.v2i0.7527

Gainju, A., Shrestha, A. K., Manandhar, S., \& Upadhyay, K. P (2018). Performance of Promising Potato Clones for Growth and Yield Characters in Bhaktapur, Nepal. North American Acaedemic Research, 2(8), 132-142.

DOI: https://doi.org/10.5281/zenodo.3372914

Gairhe, S., Gauchan, D., \& Timsina, K. (2017). Adoption of Improved Potato Varieties in Nepal. Journal of Nepal Agricultural Research Council, 4, 38-44.

DOI: https://doi.org/10.3126/jnarc.v3i1.17274

Gatto, M., Hareau, G., Pradel, W., Suarez, V., \& Qin, J. (2018). Release and adoption of improved potato varieties in Southeast and South Asia. International Potato Center. Working Paper No. 2018-2. DOI: https://doi.org/10.4160/9789290605010

Ghimire, M., Khanal, P., Manandhar, H., \& Aryal, L. (2020). Evaluation of Indigenous and Improved cultivars of potato against Late Blight (Phytphthora infestans.) in Okhaldhunga, Nepal. The Journal of Agriculture and Environment, 21, 151-162.

Ghimire, N. (2005). Adoption of Improved Potato Technology in Chitwan, Nepal . Economic Journal of Nepal, 28(3), 188-199. 
Journal of Agriculture and Natural Resources (2020) 3(2): 193-204

ISSN: 2661-6270 (Print), ISSN: 2661-6289 (Online)

DOI: https://doi.org/10.3126/janr.v3i2.32506

Gomez, K. A., \& Gomez, A. A. (1984). Statistical procedures for Agricultural research. Wiley Interscience Publications. Retrieved from https://pdf.usaid.gov/pdf_docs/PNAAR208.pdf

Hawkes, J. G., \& Francisco-Ortega, J. (1993). The early history of the potato in Europe. Euphytica, 70(1), 1-7. DOI: https://doi.org/10.1007/BF00029633/

Hijmans, R. J., \& Spooner, D. M. (2001). Geographic distribution of wild potato species. American Journal of Botany, 88(11), 2101-2112.

DOI: https://doi.org/10.2307/3558435

Ibeawuchi, I. I., Iwuanyanwu, U. P., Nze, E. O., Olejeme, O. C., \& Ihejirika, G. O. (2015). Mulches and organic manures as renewable energy sources for sustainable farming. Journal of Natural Sciences Research, 5(2), 139-147.

Joshi, B. K. (2007). Plant Breeding In Nepal: Past, Present And Future. Journal of Agriculture and Forestry University, 1, 1-33.

Khatri, B. B., \& Shrestha, S. L. (2004). Some Local Potato Cultivars and their Reaction to Viruses, 5, 19-21. DOI: https://doi.org/10.1.1.527.582

AITC. (2020). Agriculture and Livestock diary. Retrieved from https://aitc.gov.np/downloadfile/agriculture\%20diary\%202077\%20\%20final\%20up date_1596623148.pdf

Luitel, B. P., Khatri, B. B., Choudhary, D., Kadian, M. S., Arya, S., \& Bonierbale, M. W. (2016). Evaluation of advanced potato clones for plant and yield characters at high hills of Nepal. Potato Journal, 43(2), 11-124. Retrieved from file:///C:/Users/user/AppData/Local/Temp/66600-167028-1-SM.pdf

Maranzani, B. (n.d.). After 168 Years, Potato Famine Mystery Solved. HISTORY. Retrieved from https://www.history.com/news/after-168-years-potato-famine-mystery-solved

Magar, P. B. (2016). Evaluation of different potato varieties and fungicides for the management of potato late blight at Aangal, Kavre, Nepal. The Journal of University Grants Commission, 5(1), 78-87.

MoALD. (2020). Statistical information on Nepalese agriculture. Retrieved from https://www.moald.gov.np/publication/\%20Agriculture\%20Statistics

NASA power (n.d.). Prediction of Worldwide Energy Resources. Retrieved September 29, 2020, from https://power.larc.nasa.gov/

Poudel, K., \& Karkee, A. (2016). Evaluation of Potato Cultivars for Eastern High Hills of Nepal. Journal of Environmental Sciences, 2, 130-134.

Pradhan, A. M., Ar, B. C. N., \& Sarkar, K. K. (2011). Estimation of genetic parameters and association of traits related to yield in potato (Solanum tuberosum L.). Journal of Crop and Weed, 7(2), 229-23.

Shrestha, J. (2019). P-Value: A True Test of Significance in Agricultural Research, https://www.linkedin.com/pulse/p-value-test-significance-agricultural-research-jibanshrestha/. DOI: http://doi.org/10.5281/zenodo.4030711

Subedi, S., Ghimire, Y.N., Gautam, S., Poudel, H.K., \& Shrestha, J. (2019). Economics of potato (Solanum tuberosum L.) production in terai region of Nepal. Archives of Agriculture and Environmental Science, 4(1), 57-62.

DOI: https://dx.doi.org/10.26832/24566632.2019.040109

Struik, P. C. (2007). The Canon of Potato Science: 40. Physiological Age of Seed Tubers. Potato Research, 50(3), 375-377. DOI: https://doi.org/10.1007/s11540-008-9069-2

Upadhyay, K.P., Dhami, N.B., Sharma, P.N., Neupane, J.D., \& Shrestha, J. (2020a). Growth and yield responses of potato (Solanum tuberosum L.) to biochar. Agrarian Science, 31 (2): In Press. doi: 10.15159/jas.20.18. 
Journal of Agriculture and Natural Resources (2020) 3(2): 193-204

ISSN: 2661-6270 (Print), ISSN: 2661-6289 (Online)

DOI: https://doi.org/10.3126/janr.v3i2.32506

Upadhyay, K., Paudel, N., Aryal, S., Simkhada, R., Bhusal, B., \& Gautam, I. (2020b). Storability of potato varieties under ordinary storage condition in Panauti, Nepal. Sustainability in Food and Agriculture, 1(2), 51-57.

DOI: 10.26480/sfna.02.2020.51.57

Upadhyay, N., Ghimire, Y. N., Acharya, Y., \& Sharma, B. (2020c). Adoption of Improved Potato Varieties in Nepal. Black Sea Journal of Agriculture, 3(2), 139-145.

Yoo-Jeong, Y., Dungan, R.S., Ibekwe, A.M., Valenzuela-Solano, C., Crohn, D.M., Crowley, D.E., 2003. Effect of organic mulches on soil bacterial communities one year after application. Biology and Fertility of Soils. 38, 273-281. DOI: https://doi.org/10.1007/s00374-003-0639-9

Zelelew, D. Z., Lal, S., Kidane, T. T., \& Ghebreslassie, B. M. (2016). Effect of Potassium Levels on Growth and Productivity of Potato Varieties. American Journal of Plant Sciences, 7(12), 1629-1638. DOI: https://doi.org/10.4236/ajps.2016.712154/ 